\title{
Public Participation in South Africa's Policy Decision-Making Process: The Mass and the Elite Choices
}

\author{
Mokoko P. Sebola \\ Department of Public Administration, University of Limpopo, South Africa \\ mokoko.sebola@ul.ac.za
}

\section{ABSTRACT}

Public participation in policy-making dominates most Development, Political Science and Public Administration academic discourses. The issue of concern is the extent to which governments are able to create structures that allow for public participation of citizens in matters affecting their political and developmental concerns. The success of any government administration is, therefore, measured on the basis of how the citizens participate and contribute to the process of deciding their own political and developmental direction. It is argued that the public participation approach that considers the interests, contributions and needs of citizens in policy decision-making processes is difficult in practice. This article investigates the processes of public participation in public policy-making in South Africa with respect to the Choice on Termination of Pregnancy Act 92 of 1996, the Abolition of Capital Punishment policy and the Civil Union Act 17 of 2006. This is done with a view to determine if public participation in policy decision-making is a reflection of the choices of the elite or the masses.

Keywords: abortion, civil union bill, elite, public participation, public policy

JEL: ZOO

\section{Introduction}

Public participation is a contestable concept in modern public administration discourse. King, Feltey, and O'Neill Susel (1998) indicate that the concept of public in public administration has been a subject of enquiry, experimentation, revolution and controversy since the birth of the nation state. It is argued that in accordance with modern democratic principles governments have to create enabling structures for public participation in policy-making processes. A public participation model in policy decision-making that conceives the needs, interests, contributions and ideals of the entire nation has thus far proved to be difficult and impractical in policy-making and implementation. 
Public policies of the nation state are supposed to reflect the interests and needs of the citizens they are supposed to benefit.

This article investigates the processes of the South African public participation in public policy in order to determine if public participation processes in policy decision-making reflect the choices of the elite or the masses. The focus of this article is on assessing how the Termination of Pregnancy Act, the Abolition of Capital Punishment and the Civil Union Act 17 of 2006 were adopted despite the mass protests against them. The article also focuses on the conceptualisation of public participation, legislative frameworks governing public participation in South Africa, the culture of the nation and public policies, the role of the legislature in policy-making, the practices of public participation in South African governance, and whether policies adopted reflect the choices of the elite or of the masses.

\section{Conceptualising Public Participation}

According to Kanyane (2004) and Sebola and Fourie (2006) the concept of public participation is the equivalent of community participation, citizen participation and civil participation. Nzimakwe (2010), the Australia South Africa Local Governance Partnership (2012), INFED (2012), and Kemp and Hilliard (2012) regard the concept as the process of involving the public in decision-making, implementation and evaluation of programmes affecting their lives.

In South Africa, the concept public participation is used interchangeably with community participation. Whether it is public or community participation is not a subject of concern in this article. What is significant is to argue that participation in South Africa is regarded as a fundamental right in which public policies adopted are regarded as a reflection of what the South African communities in the country agreed on with their constituencies and government.

While participation relates to various concepts, it is often vulnerable to contextual abuse and misinterpretation, where it is often used to refer to public involvement. Kellermann and Kotze (1991, p. 35) indicate that participation and involvement are distinctive concepts in that participation implies a "share in" while involvement implies a feeling of belonging where people become involved because of that feeling. Participation is therefore a complex concept in which a mere passive involvement of the people in government activities does not align with the definition. Kellerman (1991, p. 52) argues that the members of the public must be able to exercise varying forms of influence in adopted programmes of action. It can be concluded that in any form of public engagement in which public influence is not considered, no public participation can be claimed to have taken place. 
South Africa does, however, have legislation in place that promotes public participation. The existence of such legislative frameworks gives South Africa the competitive advantage of democratic integrity. Garcia-Zamor (2012) shows that the significance of policy lies in its ability to balance the benefits between individuals in the society. This means that a policy pursuing the interests of selective individuals in society, lacks good ethos and intentions to achieve public good.

\section{Legislative frameworks Governing Public Participation in South Africa}

Public participation in South Africa is believed to be a mechanism by which democracy and good governance will be deepened (Public Service Commission, 2008, p. ii; Mzimakwe, 2010; Hilliard \& Kemp, 2012). The participation of people in governance and policy-making assures them that their experiential and grounded perspectives inform government of their needs and how they could be addressed. There are two legislative frameworks relevant for this discussion about public participation in South Africa. These are the Constitution of the Republic of South Africa of 1996 and the Municipal Systems Act 32 of 2000.

\subsection{Constitution of the Republic of South Africa, 1996}

Public participation in South Africa is a key constitutional principle. The Constitution of 1996 states that "people's needs must be responded to, and the public must be encouraged to participate in policy-making. Institutions, both public and private, which are in partnerships with the government, are constitutionally bound to practise public participation in policy-making and implementation" (South Africa, 1996). This implies that decisions taken by government, a public entity or the private sector without public engagement are unconstitutional and can be declared illegal.

\subsection{Municipal Systems Act $\mathbf{3 2}$ of $\mathbf{2 0 0 0}$}

The Municipal Systems Act 32 of 2000 contains a full chapter on public participation. It states in section 42(2) that "a municipal council, within the municipality financial and administrative capacity and having regard to practical considerations, has the duty to, amongst other things, encourage the involvement of local community and consult the local community about:

- the level, quality, range and impact of municipal services provided by the municipality, either directly or through other service providers

- the available options for service delivery" (South Africa, 2000).

The Municipal Systems Act (Act 32 of 2000) requires municipalities to establish mechanisms, processes and procedures to enable local communities to participate in local governance affairs (ASALGP, 2012, p. 2). The Integrated 
Development Plan (IDP) of a municipality is a significant tool to achieve public participation.

\section{Culture and Policy of the Nation State}

A British anthropologist, Edward B. Taylor, refers to culture as a complex whole range of aspects that includes knowledge, belief, art, law, morals, customs and any other capabilities and habits acquired by man as a member of society (O'Neil, 2006, pp. 1-4). Culture is regarded as complexes of learned behaviour, patterns and perceptions of life and its practices. Cliffs Notes (2012, p. 1) noted that it is through culture that people and groups are able to define themselves, conform to society's shared values and contribute to society. The concept "nation state" refers to political, economic, social and cultural actors in the international system" (Towson University, 2012, p. 1). Koopmans and Statham (1999); Rotberg (2003, pp. 1-2); Opello and Rossow (2004, p. 2), and Rabkin (2008, p. 28) also define a nation state as a state that identifies itself as deriving its political legitimacy from serving as a sovereign entity for a nation as a sovereign territorial unit. The state has an identity that is reflected by shared cultural practices common to the country's citizens.

It is, however, notable that cultural practices today are influenced by countries that play a highly influential role in the global economy. These countries are influential in the global village environment and often adopt policies that are controversial in the contextual meanings of African and other developing countries' culture (e.g. gay and lesbian marriages). Currently, whatever the governments of the United States of America (USA) and Britain view as "civilised policies" for their people have to be supported by countries that owe them loyalty because of their economic power on the international stage. Democracy in countries that owe them such loyalty is, as such, to be viewed through the eyes of the economic power.

Dewar (1997, p. 7) argues that the culture of the previous white electorate of the apartheid state (South Africa) was based on an education system that emphasised discipline and respect for authority, which were reinforced by compulsory military training for all males. Public policies were made by the ruling elite with limited right of the public to question such policy. Public participation in policy decision-making never existed. As such, the practice was that the publication of policies was made in the government gazette and only required the public to react to policies without a guarantee that their opinions would make a difference to policy adoption. The members of the public were never consulted, neither did they participate in the formulation, since only their reactions were required to legitimise and implement the policy.

Ziegenfuss, Jr (2000) notes that members of the public are to be regarded as owners and shareholders in the policy-making process. The current policymaking strategy in South Africa is said to adopt a participatory approach in 
which public participation is emphasised and practised to the extent that the public's contribution should shape the policy direction of the government. This objective, however, depends on the effectiveness of the legislature as a law-making body of the country.

\section{The role of the Legislature in Policy-Making}

Legislatures are institutions that make democratic systems function properly in government systems (Lafenwa, 2009, p. 9). The role of legislatures in policymaking is very clear and involves expressing the will of the people, passing laws and holding the government (executive) accountable. At least that is how legislatures in democratic countries are expected to function. Martin and Vanberg (2005) argue that political scientists have little knowledge of the extent to which legislatures influence policy-making in parliamentary democracies.

Rao (2011, p. 57) argues that the role of the legislature has become a constitutional requirement rather than a required constitutional role. The practical law-making environment presents a different scenario in which the executive often takes charge of the legislative role instead of carrying out their implementation function. This is not the only challenge that legislatures face in executing their roles. Other challenges include their capability to make policy information known to the public, the effectiveness of their oversight role and the ability to have systems in place to ensure proper legislative management and infrastructure.

\section{Public Participation and Policy Making in South Africa}

Public participation in policy-making is regarded as a tool in the democratic process that ensures that members of the public have an influence in policy decisions (Linklater \& Fogg, n.d., p. 2; Mzimakwe, 2010). Cloete and De Coning (2011) argue that in South Africa the process of policy management allows for participation in all spheres of government. It is fairly accepted that in South Africa the process of policy adoption is influenced by the public participation process that has taken place at both the formulation and implementation stage. Policies adopted are therefore believed to be based on the needs and interests of its citizenry.

King et al. (1998), however, argue that the participation of the public in decision-making has not been effective. This could emanate from the lack of trust that the public has developed about ruling governments (Wang \& Wan Wart, 2007). Like all other countries where public participation is a problem in policy-making, South Africa has the practice of an exploitative feudal relationship between the elite and the mass in policy-making. To a particular extent the process of policy-making can be flawed and only achieve the interests of the elite ruling class rather than be what the public requires. 
The Public Service Commission (2008, p. 10) notes that although the South African government uses a multifaceted form of public participation approaches such as information giving, consultation, material incentive, interactive and self-mobilisation, public participation itself remains a problematic model. The public participation model is not easy to apply in absolute terms. In South Africa, there are notable barriers to effective public participation in the policy-making process that include government's lack of commitment in adopting the public participation approach, limited capacity to implement the approach, a slow participation process and the mistrust between government and local communities as to this approach.

It is difficult to conclude that the public participation process in South Africa guarantees citizens that their needs and interests will be represented in the policy-making process. However, although a vast amount of literature exists as a guideline for public participation practice, it remains difficult to absolutely assert that the choice of the citizens exceeds that of the elite ruling class in policy decision-making. In arguing this, this article looks at the adoption of the three most controversial legislative frameworks in South Africa. The selection of these three is informed by the negative reactions of the majority of South African citizens to their implementation.

The negative reactions against the implementation of three legislative frameworks were presented from the perspective of both the culture and the religion of the people. These are the Choice on Termination of Pregnancy Act 92 of 1996, the Abolition of Capital Punishment, 1990 and the Civil Union Act 17 of 2006. Despite the public stir that emanated from the proposal and implementation of these frameworks, the South African ruling elite argued for them from a democratic perspective and the frameworks were adopted despite the public's disapproval.

\subsection{Choice on Termination of Pregnancy Act No 92 of 1996}

The Choice of Termination of Pregnancy Act was passed in 1996. This Act derived its legitimacy from problems emanating from unsafe and illegal terminations of pregnancies (Mhlanga, 2003; Mbele, Snyman, \& Pattison, 2006; International Gay and Lesbian Human Rights Commission, 2008) that possibly increased the high maternal mortality rate, which could have been avoided. The Choice on Termination of Pregnancy Act was enacted to improve the safety and health of women, as well as gender equality (Zeijlstra, 2006, pp. 33-37).

The public's opinion on the adoption and implementation of the Act is that it is immoral since it involves the killing of an innocent unborn baby. However, although the highest proportion of South African citizens were of the opinion that abortion is wrong, the ruling elite and the public demonstrated that they were arguing from different perspectives: the ruling elite from 
the human rights perspective, while the public from both a religious and cultural perspective.

The Christian Lawyers Association, for example, took a lead in opposing the implementation of the Choice on Termination of Pregnancy Act 17 of 1996. The organisation lost the case twice: firstly, the argument about the right to life was ruled out because a foetus does not have rights in terms of the South African law of persons (Lupton, 1994; Sithole, 2011; Pickles, 2012), and secondly, an appeal that girls of 18 and younger should get permission from parents was also ruled out. In South Africa an 18-year-old is presumed to know the consequences of his or her actions.

Table 1: Types of Religions in South Africa

\begin{tabular}{|c|c|}
\hline Churches & Number of individuals \\
\hline Dutch Reformed & $3,005,698$ \\
\hline Zion Christian & $4,971,932$ \\
\hline Roman Catholic & $3,181,336$ \\
\hline Methodist & $3,305,404$ \\
\hline Pentecostal/Charismatic & $3,422,749$ \\
\hline Anglican & $1,722,076$ \\
\hline Apostolic Faith Mission & 246,190 \\
\hline Lutheran & $1,130,987$ \\
\hline Presbyterian & 832,495 \\
\hline Bandla Lama Nazaretha & 248,824 \\
\hline Baptist & 691,237 \\
\hline Congregational & 508,825 \\
\hline Orthodox & 42,251 \\
\hline Other Apostolic churches & $5,609,070$ \\
\hline Other Zionist churches & $1,887,147$ \\
\hline Ethiopian type churches & 880,414 \\
\hline Other Reformed churches & 226,495 \\
\hline Other African independent churches & 656,644 \\
\hline Other Christian churches & $3,195,477$ \\
\hline African Traditional Belief & 125,903 \\
\hline Judaism & 75,555 \\
\hline Hinduism & 551,669 \\
\hline Islam & 654,064 \\
\hline Other beliefs & 269,200 \\
\hline No religion & $6,767,165$ \\
\hline Undetermined & 610,971 \\
\hline Total & $44,819,778$ \\
\hline
\end{tabular}

Source: SA Statistics (2007) 
South Africa claims to be a highly religious country with about six major religious groupings namely, African traditional, Buddhism, Christianity, Hinduism, Islam and Judaism. Strauss (1968, pp. 710-714) points out that abortion is a complex policy matter because, despite the problem it wants to resolve, it is measured against the concept of the soul, which is a cornerstone of religion. A religious aspect should be minimally considered in policy-making and adoption. Table 1 shows the typical South African religions.

The table reveals that South Africa is a country which is highly religious with the most popular religion being Christianity in its different forms (Zionist, Presbyterian, Lutheran, Apostle and other reformed churches). There is also a substantial grouping (more than six and a half million) that does not believe in any religion. This is probably those who do not believe in the existence of a higher spiritual authority, but at the same time that does not imply that their life styles are not informed by the social values and morals of their community culture. One would therefore expect the character of the constituency to reflect in broad terms the Christian and the African traditional belief systems. The religious groupings in South Africa, be it Christian, Hindu, Buddhist, Jewish, Muslim or African ancestral worship (Zeijlstra, 2006, p. 24-31) are, despite their different belief systems, not representatives of a society that might support abortion. They all view abortion as murder.

Abortion is a critical social problem in South Africa. In the past it was performed only if there was a convincing justification such as the birth of the child posing a life risk (physical or mental) to the mother or if the woman was raped or had conceived because of incest. Considering that the ruling elite adopt policies on the basis of rights and equality rather than morals and culture, the public participation processes conducted in the country and the implementation of these policies cannot be ruled out as having no political selectiveness favouring the interests of the elite and serving their ultimate political objective. It can therefore be argued that public hearings conducted in South Africa to legitimise abortion were indeed in the best interests of maternal health and not in the interests of public opinion. Doctors whose religious upbringing does not approve of the policy have their rights infringed if they are required to perform an abortion. It is argued that a medical practitioner with strong Catholic beliefs will not perform a surgical abortion (Zeijlstra, 2006, pp. 17-22). Therefore considering that South Africa is highly grounded in Christianity and other religions that do not subscribe to the abortion practices, the South African masses would have had little to do with the legitimisation of the abortion policy.

\subsection{Abolition of Capital Punishment, 1990}

Capital punishment is a death sentence or execution or penalty by which the crime is punishable by severing the head from the body. This form of punishment has received worldwide condemnation in the 21 $1^{\text {st }}$ century because it is viewed by Goel (2008) and the Kenya National Commission 
on Human rights (2007, pp. 1-16) as the worst degradation of the human personality imaginable. However, those that favour it justify it as preferable to the costs suffered by the state in keeping long term criminals alive as they are permanently removed from society. The death sentence is also seen as a deterrence measure (Mocan \& Gittings, 2003; Goel, 2008; Warden, 2009; Reams \& Putnam, 2011).

In South Africa, the abolition of the death penalty occurred in the late 1990s when the African National Congress (ANC) asserted that "capital punishment (should) be abolished and no further executions shall take place" (Rosenberg, 1995, pp. 1-2). This decision was hailed as a major victory for democracy in South Africa in which people's rights and dignity were protected from the inhuman punishment of the death penalty. Roux (2003, p. 2) indicates that in July 1990 the Criminal Law Amendment Act 47 of 1990 introduced changes governing the imposition of capital punishment. The Act later became a centre of criticism from both whites and blacks in the country, who regarded its relevance to the high levels of crime in South Africa.

The majority of South Africans argued that the abolition of the death penalty resulted in criminals abusing the Constitution of the Republic of South Africa, 1996 and its guarantee of the right to life, while law-abiding citizens have become victims of crime (Mwimnobi, 2004, pp. 3-4). Despite the public protests in South Africa to have the death penalty reinstated, the ruling elite managed to retain the status quo by basing their arguments on constitutional rights and the dignity of humanity and, on the other, on the fallibility of the justice system and racial discrimination, which аге highly influential factors when dealing with this kind of policy (McCann, 1996; Peffley \& Hurwitz, 2007; Goel, 2008).

The above has shown that members of the public have limited influence in policy-making, implementation and policy decision-making. The survey on attitudes to punishment, conducted by TSA (Technikon South Africa, now merged with UNISA (University of South Africa)) and ISS (Institute of Security Studies) in the Eastern Cape in 1999 demonstrates that the majority of respondents felt that murder and rape charges deserve a death sentence (Schonteich, 1999, p. 1). Christian churches were more vocal about the reinstatement of the death penalty as a solution to high levels of crime in South Africa. As Hodgkinson, Gyllensten, and Peel (2010, p. 11) attest, there is overwhelming support from the public for the death penalty; however, House (2007, p. 5) argues that support for the death penalty is symbolic in most countries. This is because the public support a state that would ensure their safety and security from criminals. Populist political leaders are likely to bow to public pressure to reinstate the death penalty without looking at the disadvantages of the policy that would in future compromise their political integrity. The factors that influence the public to rise against a particular policy adoption are to be considered and weighed carefully to determine the costs against the benefits. 
In South Africa, as Simpson and Vogelmann (2012, p. 1-6) argue, support or lack of support for capital punishment is inconsistent and is highly dependent on the levels of crime and the religion of the people. The public has been inconsistent in supporting or criticising the policy on the basis of colour or citizenship. For example, when Marriete Bosch (a South African based in Botswana) was charged and found guilty of murder, and sentenced to be hanged by the neck (capital punishment), almost all political parties and citizens in the country that support its reinstatement in their own country were totally opposed to this application of capital punishment in Botswana.

As others may argue, the South African public is inconsistent in their support or lack of support for capital punishment because they lack education about it. Of relevance to this article, it can be concluded that public opinion on the adoption of the death penalty in the country did not matter to the legislators. This, according to Roux (2003, p. 1-15), happened despite the fact that public opinion in South Africa favours the death penalty.

\subsection{The Civil Union Act 17 of 2006}

South Africa is among countries of the West and other developed countries that have adopted the Civil Union Act 17 of 2006 to legalise same sex marriage. It is probably the only country in Africa to adopt such a brave democratic stand of equality on a matter clouded by questionable moral grounds. The Constitution of the Republic of South Africa, 1996, together with its other provisions, put the country in the vanguard of global recognition of sexual rights (Norrie, 2005; Smith \& Robinson, 2006; Phillips, 2011, p. 23).

The African National Congress (ANC) acknowledged the controversial nature of the adoption of the Civil Union Bill (National Council of Provinces, 2012, p. 1) but they justified such adoption on the basis of the struggle for equality that the organisation had stood for from its inception in 1912. Honourable Thetjeng, then Democratic Alliance MP, indicated that the ruling party is aware that $99.9 \%$ of South African organisations, ranging from churches, religious and traditional groups, and ordinary citizens submitted their arguments in public hearings rejecting the adoption of the policy. But to no avail; their concerns and interests were put aside.

Jordaan (2006, pp. 1-2) is of the opinion that the controversies surrounding same sex marriage are based mainly in the religious sphere, which is distinct from the legal sphere. The acceptable assumption here from the legal perspective is that as much as the court is unable to interpret the religious script for the religious community, so can the court not be influenced by the religious values when interpreting the Constitution of the country. The two are distinct from each other in terms of function and viewpoint on life. However, it can be argued that the interpretation of the Constitution of the country outside the cultural practices of the national citizens is what the bone of contention in this policy dilemma is really. The policies of the country are to 
be informed by the belief systems of the national citizens. As much as some policies in the country allow for what is called fair discrimination, it should be considered fair only to discriminate on the basis of acceptable societal norms and values.

Ntlama (2010, pp. 1-3) argues that the rights to equality and the right to human dignity are significant when handling the same sex union bill. While the adoption of this bill is considered significant for promoting the equality of all human beings, some fundamental religious groupings in society do not understand how other sections of society can be accorded dignity for their choice of same sex practice. In reality, the application of the Civil Union Act 17 of 2006 in African society is seen as a devaluation of the African value system of the institution of marriage. Neither are the implementers of the same bill happy with what they are implementing, that they are only fulfilling the constitutional obligation with little recognition of the African value system.

The question is whose interests and needs does the Civil Union Act of 2006 fulfil in Africa and similar countries? It is reasonable to argue that the application of policies and laws cannot occur outside the context of societal values. There is a conflicting viewpoint with regard to accepting democratic practices despite the cultural values of certain countries. In Gambia, for example, following the enactment of the 1965 Criminal code, article 144 of the same code states that "homosexual acts between men or women are unnatural offences and offenders can be imprisoned for up to 14 years" (International Gay and Lesbian Human Rights Commission, 2008).

This policy framework may not be able to protect the culture of the Gambians if they define their own development from the perspective of the International Human Rights Obligation. This is considering the fact that most organisations fighting for these rights are not based in developing countries and if fighting within the borders of a developing country, they base their reasons on foreign laws and principles. From the perspective of African politics, homosexuality is the worst abomination and therefore most African governments outlawed it (Phillips, 2011; Azuah, 2011; Cobbinah, 2011; Chibwezo, 2011). This indicates that homosexuality has existed among all human nations, including in Africa where it was outlawed.

The male-dominated cultural systems in Africa have learned to discriminate against the minority, which is contradictory to the globally held democratic principles of modern governments that minority interests are important as long as there is reasonable constitutional justification. This continues to be a challenge to the African culture in which lobola has to be paid by the bridegroom to the bride's family. However, even though civil marriage is preferred by most Africans, lobola is still believed to be a validation of a marriage of African families (man and woman). 
The new marriage system based on democracy and equality of human beings (The South Africa Law Reform Commission) rarely recognises the African marriage system that was based on culture. Herbst and Du Plessis (2008) argue that in South Africa lobola is no longer a requirement for any other recognised marriage. The acceptance of this by the South African legal system shows that the African value system is not fairly considered in the modern democracy. Therefore the adoption of public policies are not necessarily informed by what the citizens believe to represent their specific cultural values, but instead are guided by the adopted policies of highly influential countries on the globe.

\section{Public or the Elite choice?}

From the argument raised in this article it is difficult to pronounce if the policy choice reflects the character of the public or that of the elite. According to Cloete and De Coning (2011), the practice of policy management in South Africa allows for public participation in all phases of policy-making and decisions. The country is well known for its well-established mechanisms and legal processes for public participation. The existence of such clear processes and mechanisms as acclaimed, however, does not guarantee that policymaking and decisions are free from implementation flaws. In adopting and making policy choices, it is believed that the government uses public opinion as a yardstick to determine the acceptability of a particular policy direction and choice.

In South Africa the government uses forms such as public hearings, makgotla and imbizo's for policy-making and decisions. It is believed that processes of this nature assist government to make rational policy decisions guided by public opinion rather than the elite's opinion. Thus far it may seem that in other instances public opinion has not been considered in South Africa (Meshoe, 2006, p. 2). This is because despite the overwhelming objections by Marriage Alliance, which represents millions of Christians, groups of churches, community groups and the Congress of Traditional Leaders Association (CONTRALESA), the Civil Union Act 17 of 2006 was adopted to legalise the public expressions of same sex marriage.

Maybe the ANC ruling elite allowed this for a fair reason, in that Maddox and Fuguay (1981) define "public opinion" as articulated group attitudes that are not necessarily the viewpoint held by society as a whole, but rather a conglomerate of attitudes as expressed by different groups. This means that a government willing to accommodate the interests and needs of the minority within society would disregard viewpoints held by the majority. In this regard the adoption of the policy choice becomes indeed an elite rather than a public choice. In South Africa, the constitutional court has on several occasions ruled against adopted policies, where it was discovered that policymaking and decisions were flawed. The major flaws in this regard were about the public participation processes. The contenders of such processes are 
satisfied when such processes are reversed. However, the government thus far reversed some and then conducted selective participation processes to legitimise and continue their implementation.

The South African government uses the system of trias politika in which the division of scope between the legislature, executive and the judicial authority is very clear. But as in other countries, the legislature faces the challenge of being dominated by the executive body in influencing policy-making, instead of only implementing policies. The adoption of the Growth, Economic and Redistribution (GEAR) programme as a non-negotiable macro-economic policy in South Africa is a good example of the undermining of the role of the legislature in policy-making. Pressures from unions and other interest groups on this policy have shown that the elite choice takes precedence over that of the public.

The concept of public participation has different meanings to different individuals and their organisations (De Villiers, 2001, p. 4). The concept has always been applied in a selfish manner by political organisations. It is understood that the way public participation takes place in most political gatherings reveals it to be a tool of people with access to power to exercise their authority upon the powerless public. In most instances where incidents referred to as public hearings or participation were conducted, the socioeconomic character of the participants determined the decisions taken at the gathering.

It can be argued that in South Africa, because of the high level of socioeconomic imbalances, the powerless members of society are unlikely to be able to influence policy-making and decisions. AfriMAP and Open Society Foundation for South Africa (2006, p. 14) indicate that in South Africa since 1999 public policy discussions have become so common that public hearings that follow afterwards in the legislatures are merely a means of legitimisation, rather than a channel through which citizens could help in shaping policymaking and decisions. Therefore it can be concluded from this that policymaking through public participation in government has become more of a legal requirement than a genuine process of policy and decision-making. Policies will therefore always be influenced by the elite or the ruling class within society rather than by mass members of the public.

\section{Conclusion}

This article argues that the notion of public participation in South Africa with regard to policy-decision and policy-making is not representative of public opinion. It is in most cases a reflection of the interests of the elite in government circles. Such interests are often not guided by what the public believe in as a social system. Some policy decisions that are said to have been supported by the public are in contrast with the value systems of the citizens concerned, and that is often followed by public and civil contestations about 
adopted policies. This reveals a high level of flaws associated with the public participation processes. Such a revelation may lead to the conclusion that public participation processes in decision and policy-making are not a true reflection of what the citizens in the country want, but instead a reflection of what the ruling elite desires.

This article therefore concludes that the adoption of the three legislative frameworks in South Africa, the Termination of Pregnancy Act No.17 of 1996, the Capital Punishment and the Civil Union Act No. 17 of 2006 were not a true reflection of what South African citizens required. Despite the public participation that characterises the South African government policy-making process, the adoption of the legislation was challenged by the majority of the citizens and civil organisations in the country without success. Despite the existence of proof from public gatherings and public protests against the adoption, the government continued with the adoption. Which is argued from the perspective that the ruling elite knows what is in the best interest of the society.

Dr. Mokoko Sebola is professor of Public Administration and Director of the School of Economics and Management at the University of Limpopo. He holds a Masters degree in Development Studies from the University of Limpopo and a Doctoral degree in Public Management from the Tshwane University of Technology. His research interest includes local government, public policy, education and governance, migration, emigration and immigration, ethics, ecotourism and local economic development. Professor Sebola has published widely in national and international journals, presented papers at national and international conferences. He is also holder of the following awards: Overall Best Established Researcher, University of Limpopo (2011), Distinguished Academic Awards, SAAPAM (2014) and Overall Best Established Researcher, University of Limpopo (2015). 


\section{References}

ASALGP - Australia South Africa Local Governance Partnership. (2012). A tool kit to support public participation in local governance. Australia: Australia South Africa Local Governance Partnership.

Azuah, O. (2011). Extortion and blackmail of Nigerian lesbians and bisexual women. In R. Thoreson \& S. Cook (Eds.), Nowhere to turn: Blackmail and extortion of LGBT people in Sub Saharan Africa (pp. 46-95). Brooklyn: Minuteman Press.

Chibwezo, W. (2011). Blackmail among gay people in Malawi. In R. Thoreson \& S. Cook (Eds.), Nowhere to turn: Blackmail and extortion of LGBT people in Sub Saharan Africa (pp. 74-88). Brooklyn: Minuteman Press.

Cobbinah, M. (2011). "Because of you": Blackmail and extortion of gay and bisexual men in Ghana. In R. Thoreson \& S. Cook (Eds.), Nowhere to turn: Blackmail and extortion of LGBT people in Sub Saharan Africa (pp. 60-73). Brooklyn: Minuteman Press.

Cliffs Notes. (2012). Culture and society defined. Retrieved 20 August 2012, from www.cliffs notes.com

Cloete, F., \& De Coning, C. (2011). Improving public policy. Pretoria: Van Schaik Publishers.

De Villiers, S. (2001). A people's government. The people's voice. Pretoria: Government Printer.

Dewar, N. (1997). Emerging societal involvement in city management: A case of Cape Town. European Journal of Geography, 1-16.

Garcia-Zamor, J.-C. (2012), Public participation in urban development: The case of Leipzig, Germany. Journal of Public Administration and Policy Research, 4(4), $75-83$.

Goel, V. (2008). Capital punishment: A human rights examination case study of jurisprudence. International NGO Journal, 3(9), 132-161.

Herbst, M., \& Du Plessis, W. (2008). Customary Law v Common Law Marriages: A hybrid approach in South Africa. Electronic Journal of Comparative Law, 1(12.1), 1-15.

Hodgkinson, P., Gyllensten, L., \& Peel, D. (2010). Capital punishment: Briefing paper. London: London Westminster University Law School, Centre for capital punishment studies.

House, R. (2007). The clear penalty and the principles of goodness. Available at https://eprints.usq.edu.au/2886/1/death-policy.pdf

INFED. (2012). Community participation. Retrieved 31 January 2012, from www. infed.org

International Gay and Lesbian Human Rights Commission. (2008). Available at http://iglhrcarchive.org/

Jordaan, D. (2006). Same sex marriage vs. civil unions: An overview of arguments. Pretoria: Centre for International Political Studies.

Kanyane, M. H. (2004). Community participation in policing. In M. J. Mafunisa \& M. H. Maserumule (Eds.), Cases in Public Administration and Management: a South African perspective. Cape Town: Heinemann Publishers.

Kellerman, G. E. J. (1991). Implementation of development projects and programmes. In F. De Beer \& D. A. Kotze (Eds.), Development Administration: A holistic approach. Pretoria: J. L. Van Schaik Publishers. 
Kellerman, G. E. J., \& Kotze, D. A. (1991). Participation and managerial approaches to development. In F. De Beer \& D. A. Kotze (Eds.), Development Administration: A holistic approach. Pretoria: J.L. Van Schaik Publishers.

Kenya National Commission on Human Rights. (2007). Abolition of the death penalty in Kenya (Position paper no. 20 of 2007). Kenya: KNCHR.

King, C. S., Feltey, K. M., \& O'Neill Susel, B. (1998). The Question of Participation: Toward Authentic Public Participation in Public Administration. Public Administration Review, 58(4), 317-326. DOI: 10.2307/977561

Koopmans, R., \& Statham, P. (1999). Challenging the Liberal Nation-State? Postnationalism, Multiculturalism, and the Collective Claims Making of Migrants and Ethnic Minorities in Britain and Germany. The American Journal of Sociology, 105(3), 652-696. DOI: 10.1086/210357

Lafenwa, S.A. (2009). The legislature and the challenges of democratic governance in Africa: The Nigerian Case. United Kingdom: University of Leeds.

Linklater, D., \& Fogg, S. (n.d.). Community participation in policy-making: The NSW advisory committee on ageing model. Available at http://www.maca.nsw.gov. au/_data/assets/pdf_file/0017/141524/Comm_participation_policy_making.pdf

Lupton, D. (1994). Medicine as Culture: Illness, Disease and the Body in Western Societies. London: Sage Publications.

Maddox, R. W., \& Fuquay, R. F. (1981). State and local government. New York: Van Nostrand.

Martin, L. W., \& Vanberg, G. (2005). Coalition policy making and legislative review. American Political Science Review, 99(1), 93-105. DOI: $10.1017 /$ S0003055405051518

Mbele, A. M, Snyman, L., \& Pattinson, R. C. (2006). Impact of the choice on Termination of Pregnancy Act on maternal morbidity \& mortality in the west of Pretoria. South African medical Journal, 96(11), 1196-1198.

McCann, E. M. (1996). Opposing corporal punishment: A prosecutor's perspective. Marquette Law Review, 79(3), 649-706. Available at http://scholarship.law.marquette.edu/mulr/vol79/iss3/3

Mhlanga, R. E. (2003). Abortion: developments and impact in South Africa. British Medicine Bulletin, 67(1), 115-26. DOI: 10.1093/bmb/ldg006

Mocan, H. N., \& Gittings, R. K .A. J. (2003). Getting Off Death Row: Commuted Sentences and the Deterrent Effect of Capital Punishment. Journal of Law \& Economics, 46(2), 453-477. DOI: 10.1086/382603

Mwimnobi, O. S. (2004). A reasonableness of reinstating the death penalty in South Africa: A juridico-philosophical approach. Paris: Penal Reform International.

National Council of Provinces. (2012). Consideration of Bill and of report of select committee on social services thereon. Pretoria: Government Printer.

Norrie, K. M. (2005). Marriage and Civil Partnership for Same-Sex Couples: The International Imperative. Journal of International Law \& International Relations, 1(1-2), 249-259.

Ntlama, N. (2010). A Brief Overview of the Civil Union Act. Potchefstroomse Elektroniese Regsblad, 13(1), 191-234. DOI: 10.4314/pelj.v13i1.55360

Nzimakwe, T. (2010). Public participation and engagement in local governance: A South African perspective. Journal of Public Administration, 45(4), 501-519.

O'Neil, D. (2002). What is culture? Retrieved 25 April 2012, from http://www.anthro.palomar.edu 
Opello, W. C. Jr., \& Rosow, S. J. (2004). The Nation-State and Global Order: A Historical Introduction to Contemporary Politics (2nd ed.). Lynne Rienner Publishers.

Peffley, M. \& Hurwitz, J. (2007). Persuasion and resistance: Race and the death penalty in America. American Journal of Political Science, 51(14), 996-1012. DOI: $10.1111 / \mathrm{j} .1540-5907.2007 .00293 . x$

Phillips, O. (2011). Blackmail in Zimbabwe: Troubling the narratives of sexuality and human rights. In R. Thoreson and S. Cook (Eds.), Nowhere to turn: Blackmail and extortion of LGBT people in Sub Saharan Africa (pp. 19-45). Brooklyn: Minuteman Press.

Pickles, C. (2012). Termination of Pregnancy Right and Social Interest in Continued Existence in South Africa: The Choice on Termination of Pregnancy Act 92 of 1996. Potchefstroomse Elektroniese Regsblad, 15(3), 403-638.

Public Service Commission. (2008). Report on the assessment of public participation practices in the public service. Polokwane: Public Service Commission.

Rabkin, J. (2008). Freedom and the Nation-State: The nation-state is the best insurance for liberty. The American Spectator, November 2008.

Reams, T. M., \& Putnam, C. T. (2011). Making the Case for the Dereference Effect of Corporal Punishment. New Hampshire Bar Journal, 52(2), 18-20.

Rao, M. V. (2011). Public policy formulation: Role of different agencies. India: University of Hyderabad.

Rosenberg, T. (16 July 1995). The Deadliest D. A. New York Times Magazine.

Roux, J. (2003). The impact of the death penalty on criminality. Paper presented at a conference on Convergence of Criminal Justice Systems: Building Bridges - Bridging the Gaps. Hosted by the International Society for the Reform of Criminal Law in August 2003 in The Hague, The Netherlands.

Rotberg, R. I. (Ed.). (2003). When States Fail: Causes and Consequences. Princeton University Press.

SA Statistics. (2007). South African Statistics, 2007. Retrieved from http://www.statssa.gov.za/publications/SAStatistics/SAStatistics2007.pdf

Schonteich, M. (1999). Sentencing in South Africa: Public perception and judicial process (Occasional Paper no. 43). Pretoria: Institute for Security Studies.

Sebola, M. P., \& Fourie, L. de W. (2006). Community participation in ecotourism destinations: Maleboho Nature Reserve. In C. A. Brebbia and F. D. Pineda (Eds.), Sustainable Tourism II, WIT Transactions on Ecology and the Environment, 97 (pp. 193-204). Witpress. DOI: 10.2495/st060181

Simpson, G. \& Vogelman, L. (2012). The death penalty in South Africa. Pretoria: Centre for the Study of Violence and Reconciliation.

Sithole, S. (2011). Stem on research the regulatory - the framework in South Africa. SA Journal of Bioethics \& Law, 4(2), 1-4.

Smith, B. S., \& Robinson, J. A. (2006). The South African Civil Union Act 17 of 2006: A good example of the dangers of rushing the legislative process. Brigham Young University Journal of Public Law, 22(2), 419-438.

South Africa (Republic). (1990). Abolition of Capital Punishment, 1990. Pretoria: Government Printer.

South Africa (Republic). (1996). Constitution of the Republic of South Africa, 1996. Pretoria: Government Printer. 
South Africa (Republic). (2000). Municipal Systems Act 32 of 2000. Pretoria: Government Printer.

Strauss, S. A. (1968). Therapeutic Abortion: Two Important Judicial Pronouncements. South African Medical Journal, 46(3).

Towson University. (2012). What is a nation state? Retrieved 20 August 2012, from www.towson university.edu

Wang, XH, \& Van Wart, M. (2007). When Public Participation in Administration Leads to Trust: An Empirical Assessment of Managers' Perceptions. Public Administration Review, 67(2), 265-78. DOI: 10.1111/j.1540-6210.2007.00712.x

Warden, R. (2009). Reflections on corporal punishment. North-Western Journal of Law \& Social Policy, 4(2), 299-359.

Zeijlstra, M. (2006). Ik ben niet anti-man. Delta, 38(30). (I'm not anti-male'; Intterview with the first leader of the Delft University of Technology professional women's network)

Ziegenfuss, J. T. Jr. (2000). Building Citizen Participation: The Purposes, Tools \& Impact of Involvement. XIV Concurso de Ensayos del CLAD "Administración Pública y Ciudadanía". Caracas, 2000. 
POVZETEK

1.02 Pregledni znanstveni članek

\section{Sodelovanje javnosti v postopku odločanja o politiki v Južni Afriki: izbire množic in elite}

Sodelovanjejavnosti prioblikovanju politikje aktualna temavvečiniakademskih razprav na področju razvoja, politologije in javne uprave. Vprašanje je, v kolikšni meri lahko država oblikuje strukture, ki omogočajo javno sodelovanje državljanov v zadevah, ki vplivajo na njihove politične in razvojne probleme. Uspeh državne uprave se zato ocenjuje na podlagi tega, kako državljani sodelujejo v postopku odločanja o svoji politični in razvojni usmerjenosti ter kako k temu prispevajo. Pristop sodelovanja javnosti, ki upošteva interese, prispevke in potrebe državljanov v postopkih odločanja o politiki, v praksi velja za težkega. Ta članek proučuje postopke sodelovanja javnosti pri oblikovanju javne politike v Južni Afriki v zvezi z Zakonom o prekinitvi nosečnosti št. 92 iz leta 1996, s politiko odprave smrtne kazni in z Zakonom o registrirani skupnosti št. 17 iz leta 2006. Namen članka je ugotoviti, ali je sodelovanje javnosti pri odločanju o politiki odraz izbir elite ali množic. 